\title{
CERCARIAE OF TREMATODES IN FRESHWATER SNAILS IN THREE CLIMATIC ZONES IN SRI LANKA
}

\author{
Uthpala A. Jayawardena ${ }^{1,2}$, Rupika S. Rajakaruna ${ }^{1 *}$ and Priyanie H. Amerasinghe ${ }^{3}$ \\ ${ }^{1}$ Department of Zoology, Faculty of Science, University of Peradeniya, Sri Lanka \\ ${ }^{2}$ Postgraduate Institute of Science, University of Peradeniya, Sri Lanka \\ ${ }^{3}$ IWMI, C/O ICRISAT, Patancheru - 502 324, Hyderabad, Andhra Pradesh, India \\ Accepted 19 December 2010
}

\begin{abstract}
Cercariae of trematodes in freshwater snails were studied in 1694 snails collected from rivers and streams in three climatic zones of Sri Lanka during 2005 to 2008. Four snail species; Thiara scabra, T. tuberculata, Paludomous sphearica and Gyraulus saigonensis were collected from nine sites in four districts; Matale, Kandy, Kegalle, and Kurunegala. Snails were allowed to release cercariae under direct sunlight or artificial light in the laboratory. Of the four snail species collected, Thiara spp. was the most preferred intermediate host with high prevalence of infection. Eight different morphological types of cercariae were released namely; oculopleurolophocercous, distome, gymnocephalous, echinostomous, gymnophallus, xiphidiocercariae, macrocercous and two furcocercous type cercariae. These cercariae belonged to six trematode families; Heterophyidae, Schistosomatidae, Psilostomidae, Echinostomidae, Gymnophallidae, Lecithodendriidae and two unidentified groups. Of the snails collected, $16 \%$ was infected with one or more types of cercariae. The highest overall infection was $77.4 \%$ in snails collected from Kurunegala district, of which more than $90 \%$ was Thiara spp. One snail with mixed infections was found. Diversity and prevalence of cercariae varied among the three climatic zones. The highest diversity was observed in the wet zone (Shannon Diversity Index, $\mathrm{H}=-1.423$ ) showing six morphotyes. The diversity of infection in the dry zone was very low $(\mathrm{H}=-0.192)$ with only two morphotypes. Although, the cercariae diversity was very high in the wet zone, the prevalence of infection was very low $(10.1 \%)$ compared to the dry $(77.4 \%)$ and intermediate $(33.9 \%)$ zones.
\end{abstract}

Key words: Digenetic trematodes, cercariae diversity, freshwater snails

\section{INTRODUCTION}

Digenetic trematodes, commonly known as flukes, are responsible for a number of disease conditions in humans and many other vertebrates. They have a heteroxenous life cycle with freshwater snail as their first intermediate host. The adult stages are found in different vertebrate definitive hosts including amphibians, fishes, reptiles, birds and mammals. Disease characteristics of fluke infections vary with the parasite species and the site or organ of infection and are linked with the life cycle events like larval penetration, egg laying, etc.

Many species of freshwater snails serve as intermediate hosts for digenetic trematodes. Consequently, the distribution of freshwater snails accounts for the occurrence of different trematode taxa in a particular region. As the

*Corresponding author's email: rupikar@pdn.ac.lk parasites are mostly host specific, higher heterogeneity of the host promotes higher heterogeneity of the parasites (Hechinger and Lafferty, 2005). Similarly, higher snail diversity leads to higher trematode diversity. Apart from that, conditions influencing the proliferation of snail population will inevitably enhance the existence of trematode parasites in their intermediate host. Some riverine habitats provide physicochemical conditions that favor the proliferation of freshwater snail fauna, for this reason, environmental conditions in different habitats, in different climatic zones may support the trematode life cycle differently. Trematodes show distinct and direct relationship with the temperature in their transmission process (Smyth, 1962; Poulin, 2005). Cercarial output is directly influenced by the temperature due to both stimulating effect of temperature increasing the emergence from the snail and the acceleration of cercarial production within the 
snail host (Poulin, 2005). The combined effect of the two will increase the cercariae release in great numbers. However, under high temperature conditions some cercariae encyst within snails. Even though, snail populations grant higher trematode diversity, trematodes can affect snail populations by directly reducing the egg production or by increasing snail mortality rates (Lafferty, 1993).

The daily cycles of cercarial emergence are recognized as an adaptive mechanism to enhance parasite transmission. Several hypotheses have been proposed to explain the functional significance of these daily cycles (Shostak and Esch, 1990). The most accepted hypothesis suggests that cercarial emergence is timed to coincide with the presence of the next host, particularly for those cercarial species in which the target hosts do not regularly cohabit with the molluscan host producing the cercariae (Combes et al., 1994).

Prevalence and intensity of infection are the major determinant factors of the rate of transmission of digenetic trematodes from the snail-intermediate host to the next host in their life cycle (Margolis et al., 1982; Anderson and May, 1991). Release of cercariae out of their snail intermediate host is a measure of intensity of that particular trematode infection.

Classification of digeneans is a complicated task, but the larval characters of the digeneans can also be used in classification (Brooks et al., 1985). Four types of cercariae are described depending on the position and number of suckers namely, monostome, amphistome, gasterostome and distome; while 11 monotypes are described by the shape and relative size of the tail; pleurolorphocercous, cystocercous, furcocercous, microcercous, gymnophallus, macrocercous, leptocercous, trichocercous, cercariaea, rat-king and cotylocercous (Cheng, 1986). Presence of other body structures such as collar spine (echinostome), anterior stylet (xiphidiocercariae), eyespots (ophtalmocercariae) are also being used (Cheng, 1986).

This study was designed to determine the diversity, prevalence and the production of different cercariae morphotypes in freshwater snails collected from selected sites in different climatic zones of Sri Lanka.

\section{MATERIALS AND METHODS}

\section{Study sites}

Study sites were selected to cover the three major climatic zones of Sri Lanka; dry zone, intermediate zone and wet zone. Two sampling sites in Kandy District; Mahaweli River at Peradeniya and Sarasavi Oya at Peradeniya and one site in Kegalle District; Maha Oya at Hingula were selected in the wet zone. In the intermediate zone tributaries of Mahaweli River; Mirisgoni Ela at Thalakiriyagama and Mirisgoni Oya at Wahakotte and Meda Ela at Palapathwala (Matale District) were selected. Two sites along the Deduru Oya including Ibi Ela at Ibbagamuwa and Ma Oya at Pannala and another site along the Hakwetuna Oya at Malsiripura (Kurunegala district) were selected in the dry zone (Fig. 1).

\section{Sampling and identification of snails}

An area of about $200 \mathrm{~m}$ along the stream was selected for snail sampling in each study site. Timely collection was conducted such that all the snails found within 2 hour period were taken as one sampling event in a particular site. The selection of sites was based on easy access to the stream, presence of livestock grazing areas or where birds and other wildlife visit the stream for water and food. Snails were collected from March 2005 to May 2008 either using a kitchen sieve or hand picked from rocks or stream bottom. Riparian vegetation was closely inspected to find any snails attached to leafsurfaces. Each site was sampled four times during the study period. The substratum in these areas was rocky, sandy or muddy with decaying leaves. Snails were placed in glass bottles filled with water from the same habitat and were brought to the laboratory inside a cooler containing ice to avoid overheating during transportation. Snails were identified according to the morphological features of the shell using keys of Mendis and Fernando (2002) and Naggs and Raheem (2000).

\section{Shedding and harvesting of cercariae}

Snails were placed separately in small plastic specimen cups containing $25 \mathrm{ml}$ of dechlorinated tap water. They were then exposed to $12 \mathrm{~h}$ light period (sunlight or artificial light) to induce shedding of cercariae. This setup was left undisturbed in the laboratory at room temperature up to 30 days. Each snail was carefully observed under a dissecting microscope several times a day for cercariae shedding. Once a snail completed shedding, it was taken out of the container and the cercariae 
were separated out. Daily renewal of the dechlorinated tap water medium was continued throughout the study period to avoid $\mathrm{pH}$ changes in the medium.

\section{Identification and counting of cercariae}

Cercariae released by the snails were isolated and slide mounted using single-staining procedure in Borax-Carmine. Identification of cercariae was carried out using descriptions and keys in Yamaguti (1975), Cheng (1986), Faltynkova et al. (2008) and Wessenburg-Lund (1931). Live unstained specimens and stained cercariae were identified to the family level based on the morphological characteristics and swimming behaviour where possible. Cercariae were nartcotised by placing in $0.35 \% \mathrm{NaCl}$ solution and the length was measured using a calibrated eyepiece graticule. Length of the body, tail, furcae and the distance between the two suckers were measured and used in identification.

Prevalence of infection was determined as a percentage, by taking the number of snails that released cercariae, divided by the total number of snails collected from a particular site. The number of cercariae released per snail was counted using a Sedgwick Rafter Cell. Counting was carried out until no cercaria was released by the infected snail.

\section{Data analysis}

Shannon Diversity Index $(\mathrm{H})$ was calculated using the number of different species and relative abundance of each species in the three climatic zones and were compared using a $t$ test for significant differences. The prevalence of infection was compared among the three zones using a chi square test.

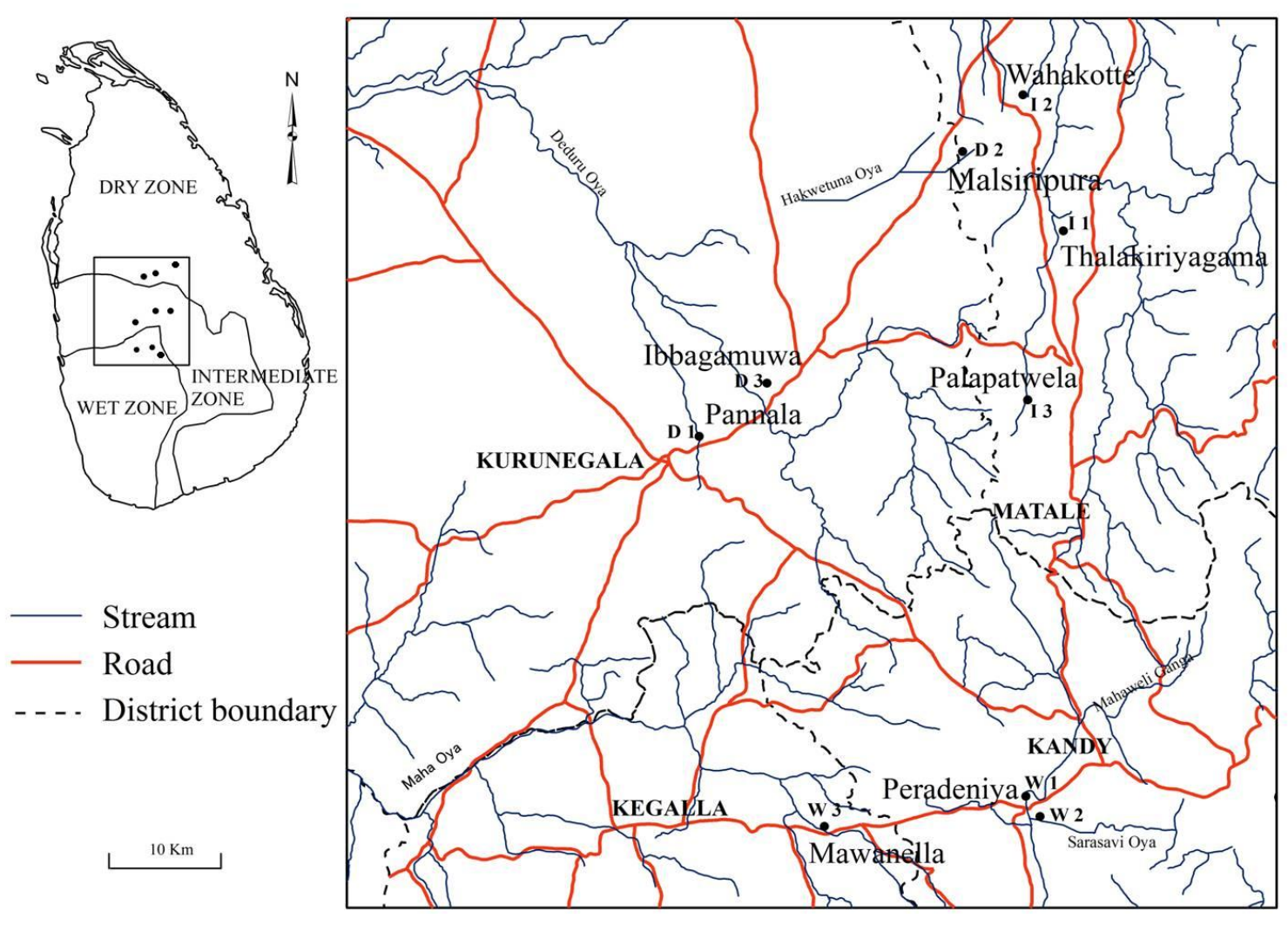

Figure 1. Map showing sampling sites in four districts in the three major climatic zones of Sri Lanka. 


\section{RESULTS}

\section{Snail hosts}

A total of 1694 freshwater snails were collected from the study sites (Table 1). Snails belonging to four different species, representing 3 genera were collected namely; Thiara scabra, T. tuberculata, Paludomous sphaerica and Gyraulus saigonensis (Fig. 2). The two Thiara species were found in all three zones while Gyraulus saigonensis was found only in the wet zone. Paludomus sphearica was not found in the dry zone (Table 1). In general, diversity and abundance of snails were high in the wet zone compared to the dry and intermediate zones.

\section{Shedding of cercariae and their diversity}

Three of four snail species collected; $T$. scabra, T. tuberculata and P. sphearica, shed cercariae. Gyraulus saigonensis did not release any cercairae. Of the 1694 snails collected, 284 (16\%) released one or more types of cercariae (Table 2). Lowest prevalence of infection was from the snails collected from the wet zone $(10.1 \%)$. Although, the number and type of snails collected in the dry zone was low, a large percentage was infected with cercariae $(77.4 \%)$.

Table 1. Species of freshwater snails collected from study sites in three different climatic zones.

\begin{tabular}{|c|c|c|c|c|c|}
\hline \multirow{5}{*}{ Climatic Zone } & \multicolumn{4}{|c|}{ Number of snails (\%) } & \multirow{5}{*}{ Total } \\
\hline & \multirow{2}{*}{\multicolumn{3}{|c|}{$\begin{array}{c}\text { Family } \\
\text { Thiaridae }\end{array}$}} & \multirow{4}{*}{$\begin{array}{c}\text { Family } \\
\text { Planorbidae } \\
\text { Gyraulus } \\
\text { saigonensis }\end{array}$} & \\
\hline & & & & & \\
\hline & Thiara & Thiara & Paludomous & & \\
\hline & tuberculata & scabra & sphearica & & \\
\hline Wet zone & $186(13.9)$ & $189(14.2)$ & $945(71)$ & $11(0.8)$ & $1331(79)$ \\
\hline Intermediate zone & $94(30.3)$ & $198(63.9)$ & $18(5.8)$ & - & $310(18)$ \\
\hline Dry zone & $13(24.5)$ & $40(75.4)$ & - & - & $53(3)$ \\
\hline Total & $293(17.1)$ & $427(24.7)$ & $963(56.9)$ & $11(0.6)$ & 1694 \\
\hline
\end{tabular}

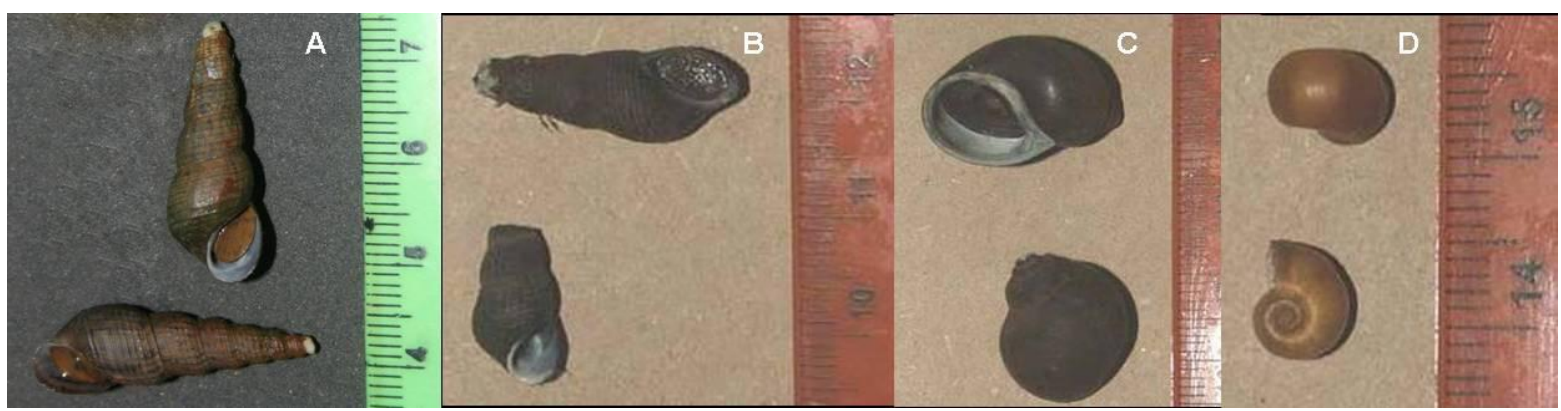

Figure 2. The four different species of freshwater snails collected from the study sites. A - Thiara scabra B- Thiara tuberculata C-Paludomous sphearica D- Gyraulus saigonensis 
Table 2. Prevalence of cercariae in freshwater snail species collected from different sampling sites in three climatic zones.

\begin{tabular}{|c|c|c|c|c|c|c|}
\hline \multirow{3}{*}{ Climatic zone } & \multirow{3}{*}{ Sampling site } & \multicolumn{5}{|c|}{ \% Prevalence of cercariae $(\mathrm{N})$} \\
\hline & & & & & & Total \\
\hline & & Thiara tuberculata & Thiara scabra & Paludomous sphearica & Gyraulus saigonensis & \\
\hline \multirow[t]{4}{*}{ Wet Zone } & Mahaweli river & $85.7(49)$ & $80.0(10)$ & - & - & $84.7(59)$ \\
\hline & Sarasavi Oya & $31.3(16)$ & $6.1(179)$ & $5.7(934)$ & $0(11)$ & $6.0(1140)$ \\
\hline & Maha Oya & $12.4(121)$ & - & $9.0(11)$ & - & $0.12(132)$ \\
\hline & Overall & $33.3(186)$ & $10.0(189)$ & $5.7(945)$ & $0(11)$ & $10.1(1331)$ \\
\hline \multirow{4}{*}{$\begin{array}{l}\text { Intermediate } \\
\text { Zone }\end{array}$} & Mirisgoni Ela & $48.6(74)$ & $28.6(28)$ & - & - & $43.0(102)$ \\
\hline & Mirisgoni Oya & $40.0(20)$ & $23.8(84)$ & - & - & $27.0(104)$ \\
\hline & Meda Ela & - & $38.4(86)$ & $0(18)$ & - & $31.7(104)$ \\
\hline & Overall & $46.8(94)$ & $30.8(198)$ & $0(18)$ & $0(0)$ & $33.9(310)$ \\
\hline \multirow[t]{4}{*}{ Dry Zone } & Ma Oya & - & $42.1(19)$ & - & - & $42.1(19)$ \\
\hline & Hakwetuna Oya & $100(13)$ & - & - & - & $100(13)$ \\
\hline & Ibi Ela & - & $95.2(21)$ & - & - & $95.2(21)$ \\
\hline & Overall & $100(13)$ & $70.0(40)$ & $0(0)$ & $0(0)$ & $77.4(53)$ \\
\hline \multicolumn{2}{|c|}{ Overall Prevalence } & $36.0(293)$ & $35.6(427)$ & $5.6(963)$ & $0(11)$ & $16.0(1694)$ \\
\hline
\end{tabular}

$\mathrm{N}=$ Total number of snails belonging to a particular species collected at the site. 
The prevalence of infection among the sampling sites in the wet zone ranged from $0 \%$ $85.7 \%$ where $T$. tuberculata collected from Mahaweli river had the highest prevalence of infection (85.7\%; Table 2). Prevalence of cercariae in the intermediate zone ranged from $0 \%-48.6 \%$ where $T$. tuberculata collected from Mirisgoni Ela had the highest prevalence of infection (48.6\%; Table 2). In the dry zone, only Thiara spp. were found which had a very high prevalence of infection ranging from $42 \%$ $100 \%$ (Table 2). The highest prevalence of cercariae infection was observed in $T$. tuberculata in all three zones (Fig. 3).

Shedding of cercariae varied from 29 to 9843 (an average of about 566) cercariae per infected snail (Table 3). The highest was recorded in Mirisgoni Ela in the intermediate zone infected with oculopleurolophocercous (8540-9843) and furcocercous-II (7493-7806) type cercariae
(Table 3). Overall, a higher number cercariae were shed by snails collected from the dry zone.

Of the four snail species collected, Thiara spp. were the most preferred intermediate host with high prevalence of infection. The two Thiara species collected from Mahaweli River in the wet zone served as the intermediate host for oculopleurolophocercous, furcocercous-II and gymnocephalous type cercariae. Thiara scabra had a significantly higher potential as the host of gymnophallus type cercariae than $T$. tuberculata $\left(\chi^{2}=12.121\right.$, df $\left.=1, p<0.001\right)$ in the intermediate zone. In Mirisgoni Ela in the intermediate zone, both species of Thiara had equal potential in serving as an intermediate host for oculopleurolophocercous, while $T$. tuberculata supported furcocercous-II infection significantly better than T. scabra $(\chi 2=8.992$, $\mathrm{df}=1, p=0.003$ ).

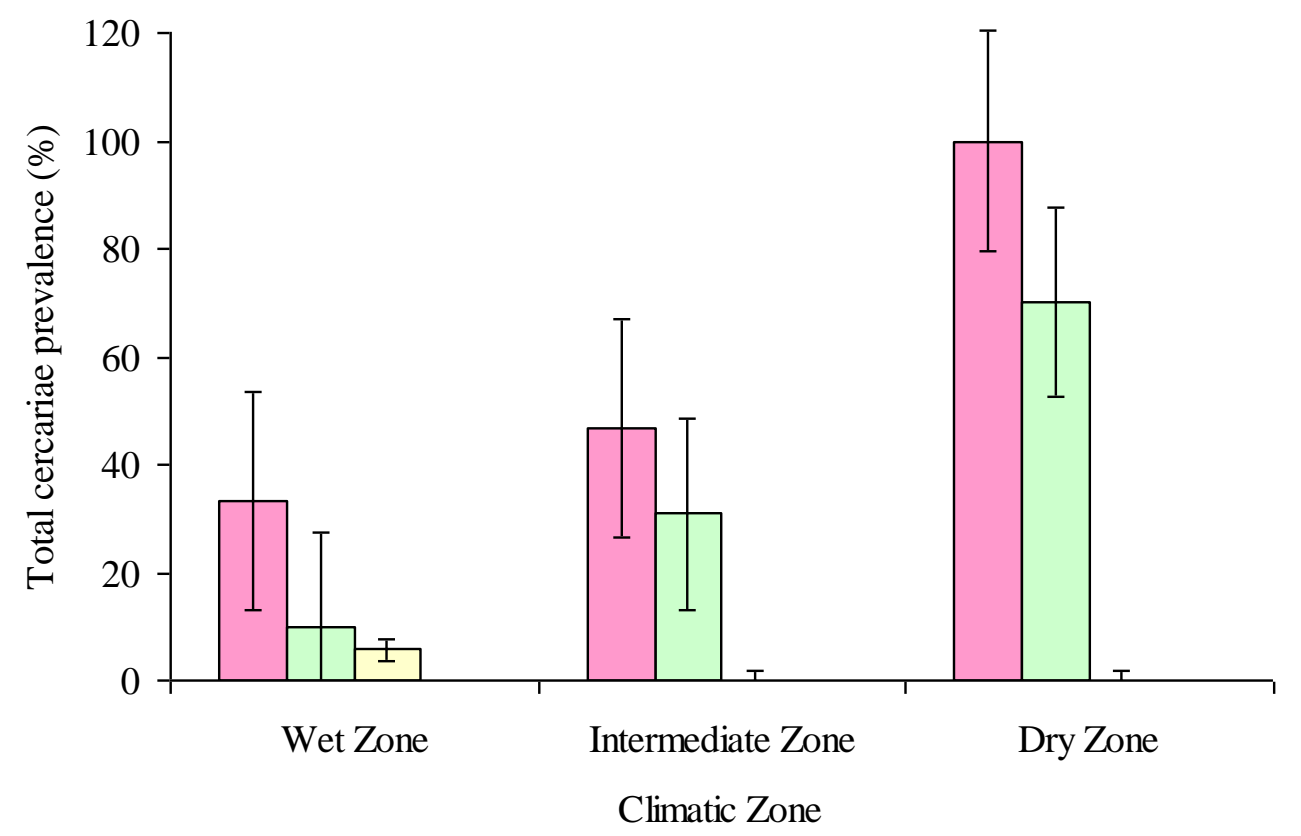

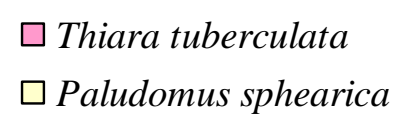

Thiara tuberculata

Paludomus sphearica

Figure 3. Total cercariae prevalence $(\%)$ in different snail species collected from three climatic zones. Gyraulus saigonensis did not release any cercariae. 
Table 3. Shedding of cercariae* by snails collected from the study sites.

\begin{tabular}{|c|c|c|c|c|c|c|c|c|c|c|}
\hline Zone /Study site & Snail species & $\begin{array}{l}\text { OC } \\
\pm \text { SD }\end{array}$ & $\begin{array}{c}\text { DT } \\
\pm \text { SD }\end{array}$ & $\begin{aligned} & \text { FC-1 } \\
\pm & \text { SD }\end{aligned}$ & $\begin{array}{l}\text { FC-2 } \\
\pm \text { SD }\end{array}$ & $\begin{array}{l}\text { GC } \\
\pm \text { SD }\end{array}$ & $\begin{array}{c}\text { EC } \\
\pm \text { SD }\end{array}$ & $\begin{array}{c}\text { GP } \\
\pm \text { SD }\end{array}$ & $\begin{array}{c}\text { XI } \\
\pm \text { SD }\end{array}$ & $\begin{array}{l}\text { MC } \\
\pm \text { SD }\end{array}$ \\
\hline \multicolumn{11}{|l|}{ Wet Zone } \\
\hline \multirow[t]{2}{*}{ Mahaweli river } & T. tuberculata & $920 \pm 76$ & - & - & $876 \pm 43$ & $97 \pm 16$ & - & $475 \pm 49$ & - & - \\
\hline & T. scabra & $156 \pm 32$ & - & - & $342 \pm 87$ & $321 \pm 42$ & - & $32 \pm 07$ & - & - \\
\hline \multirow[t]{3}{*}{ Sarasavi-Oya } & T. tuberculata & $392 \pm 15$ & - & - & - & - & - & - & - & - \\
\hline & T. scabra & - & - & - & $250 \pm 54$ & - & - & - & - & - \\
\hline & P. sphearica & - & $105 \pm 23$ & - & - & $90 \pm 06$ & - & $90 \pm 11$ & - & $140 \pm 23$ \\
\hline \multirow[t]{2}{*}{ Maha Oya } & T. tuberculata & $643 \pm 167$ & - & - & $276 \pm 27$ & $354 \pm 26$ & - & - & - & - \\
\hline & P. sphearica & $321 \pm 79$ & - & - & - & - & - & - & - & - \\
\hline \multicolumn{11}{|l|}{ Intermediate Zone } \\
\hline \multirow[t]{2}{*}{ Mirisgoni Ela } & T. tuberculata & $8540 \pm 2847$ & - & $78 \pm 22$ & $7806 \pm 945$ & - & - & - & $124 \pm 16$ & - \\
\hline & T. scabra & $9843 \pm 2256$ & - & - & $7493 \pm 1258$ & $212 \pm 16$ & - & - & - & - \\
\hline \multirow[t]{2}{*}{ Mirisgoni Oya } & T. tuberculata & $489 \pm 71$ & - & - & - & $505 \pm 29$ & - & $67 \pm 17$ & - & - \\
\hline & T. scabra & $685 \pm 42$ & - & $29 \pm 05$ & $543 \pm 26$ & $908 \pm 17$ & - & $181 \pm 09$ & - & - \\
\hline Meda Ela & T. scabra & $467 \pm 37$ & - & $51 \pm 31$ & $206 \pm 54$ & $791 \pm 38$ & - & $284 \pm 12$ & - & - \\
\hline \multicolumn{11}{|l|}{ Dry Zone } \\
\hline Ma Oya & T. scabra & $913 \pm 49$ & - & - & - & - & $61 \pm 04$ & - & - & - \\
\hline Hakwetuna Oya & T. tuberculata & $651 \pm 102$ & - & - & - & - & - & - & - & - \\
\hline Ibi Ela & T. scabra & $894 \pm 91$ & - & - & - & - & $106 \pm 19$ & - & - & - \\
\hline Overall intensity & & $1916 \pm 3248$ & $105 \pm 23$ & $52 \pm 24$ & $2224 \pm 3357$ & $370 \pm 290$ & $83 \pm 32$ & $188 \pm 167$ & $124 \pm 16$ & $140 \pm 23$ \\
\hline
\end{tabular}




\section{Diversity of cercariae types}

A total of nine different types of cercariae belonging to eight morphotypes were shed by the snails (Figs. $4 \& 5$ ). Cercariae types included oculopleurolophocercous, distome, two furcocercous, one gymnocephalous, echinostomous, gymnophallus, xiphidiocercariae and macrocercous cercariae.

\section{Oculopleurolophocercous cercariae} (Family Heterophyidae; Figs. 4A \& 5A)

The body is oval shaped $(216 \pm 24 \mu \mathrm{m})$ with a simple, long tail $(353 \pm 20 \mu \mathrm{m})$. The oral sucker is large and conspicuous compared to the small, vestigial ventral sucker. Two small eyespots are located at the anterior half of the body just behind the oral sucker. Penetration glands are located in the posterior two thirds of the body. Lateral fin folds in the basal end of the tail region were visible in the live specimens. The specimen is similar to cercariae of Stictodora tridactyla described by Yamaguti (1975).

\section{Distome cercariae}

(unknown family; Figs. 4B \& 5B)

Small, oval shaped body $(122 \pm 7 \mu \mathrm{m})$ is connected to a large, simple tail $(342 \pm 16 \mu \mathrm{m})$. The oral sucker is comparatively larger and conspicuous than the ventral sucker, located in the middle of the body.

\section{Furcocercous cercariae}

(Family Schistosomatidae; Figs. 4C \& 5C)

Long elliptical body $(396 \pm 14 \mu \mathrm{m})$ terminated with a tapering end and a forked tail. A pair of large eyespots are located anterior to the intestinal bifurcation. Granulated dark colour penetration glands are located in the anterior region and are clearly visible through the transparent body. Ventral sucker is smaller than the oral sucker and is located at the posterior two thirds of the body at a distance of $310 \pm 09 \mu \mathrm{m}$ from the oral sucker. Tail bifurcates at distal end of the tail stem $(666 \pm 14 \mu \mathrm{m})$ producing comparatively short furcae $(252 \pm 14 \mu \mathrm{m})$. This specimen is similar to the cercariae of Pseudobilharziella spp. described by Yamaguti (1975).

\section{Furcocercous cercariae}

(Family Schistosomatidae; Figs. 4D \& 5C)

Oval body $(180 \pm 35)$ ends with a forked tail. The circular oral and ventral suckers are almost similar in size. The ventral sucker lies at the posterior third of the body within $194 \pm 14 \mu \mathrm{m}$ distance from the oral sucker. Two, small eyespots are situated at the middle of the body. A triangular shaped excretory vesicle is found at the end of the head. Tail stem $(356 \pm 66 \mu \mathrm{m})$ ends with comparatively longer furcae (194 \pm 37 $\mu \mathrm{m})$. The specimen is similar to the cercariae of Gigantobilharzia sp. described by Yamaguti (1975).

\section{Gymnocephalous cercaria}

(Family Psilostomidae; Figs. 4E \& 5E)

Small pear shaped body $(87 \pm 5 \mu \mathrm{m})$ is connected to a long, simple tail $(91 \pm 19 \mu \mathrm{m})$. Terminal mouth is supported by a large oral sucker. The ventral sucker is smaller in size and located in the posterior half of the body within $51 \pm 5 \mu \mathrm{m}$ distance from the oral sucker.

\section{Echinostomous cercariae}

(Family Echinostomidae; Figs. 4F \& 5F)

Elongated oval shaped body $(97 \pm 6 \mu \mathrm{m})$ with a tail measuring $122 \pm 6 \mu \mathrm{m}$. Ventral sucker is located the middle of the body. Collar is not well marked and collar spines are difficult to observe. Oral sucker is located $64 \pm 6 \mu \mathrm{m}$ away from the ventral sucker. Presence of large number of cystogenous gland cells gave a dark appearance to the live cercariae.

\section{Gymnophallus cercariae}

(Family Gymnophallidae; Figs. 4G \& 5G)

Nonoculate, fusiform body $(338 \pm 18 \mu \mathrm{m})$ with a large anterior sucker situated terminally. The tail is completely absent. A large ventral sucker is located within a distance of $147 \pm 11$ $\mu \mathrm{m}$ from the oral sucker.

\section{Xiphidiocercariae cercariae}

(Family Lecithodendridae; Figs. 4H \& 5H)

The body $(369 \pm 24 \mu \mathrm{m})$ is elongated pearshaped with a small, wrinkled, simple tail (289 \pm $18 \mu \mathrm{m})$ located at the posterior end of the body. Dark colour appearance of the cercariae is due to granular and thick tegument. Ventral sucker is located at the mid-region of the body within 147 $\pm 6 \mu \mathrm{m}$ from the oral sucker. The anterior sucker is armed with a stylet. Pharynx lies just below the oral sucker.

\section{Macrocercous cercariae}

(unknown family; Figs. 4I \& 5I)

The body is oval shaped $(146 \pm 30 \mu \mathrm{m})$ with greatly enlarged tail $(598 \pm 206 \mu \mathrm{m})$ which is almost as wide as the body proper. The two suckers are similar in size and the ventral sucker is located at the posterior end of the body within $132 \pm 30 \mu \mathrm{m}$ distance from the oral sucker. 


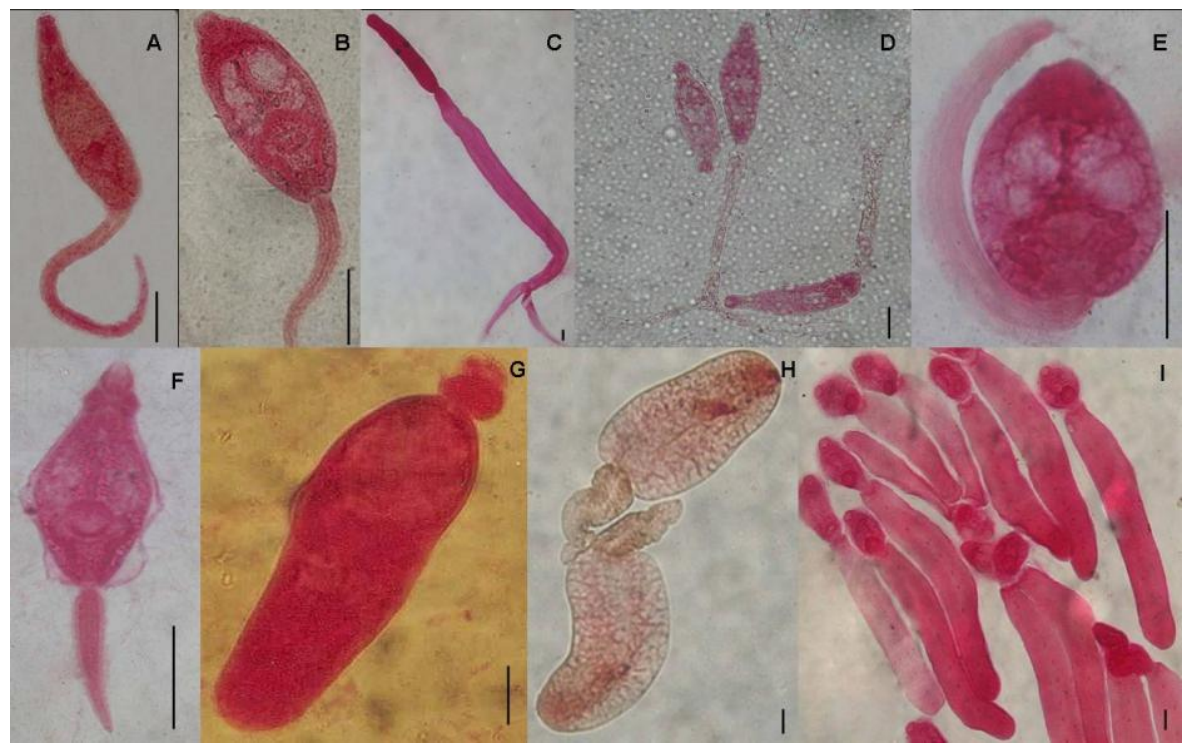

Figure 4. Different types of cercariae found in the freshwater snails; (A) Oculopleurolophocercous (Family Heterophyidae), (B) Distome - unidentified sp., (C) Furcocercous-I - Pseudobilharziella sp., (D) Furcocercous - II - Gigantobilharzia sp. (E) Gymnocephalous (Family Psilostomidae), (F) Echinostome, (G) Gymnophallus (Family Lissorchiidae), (H) Xiphidiocercous - (Astiotrema sp.), (I) Macrocercous cercariae. (Scale bar $=\mathbf{5 0} \mu \mathrm{m}$ )
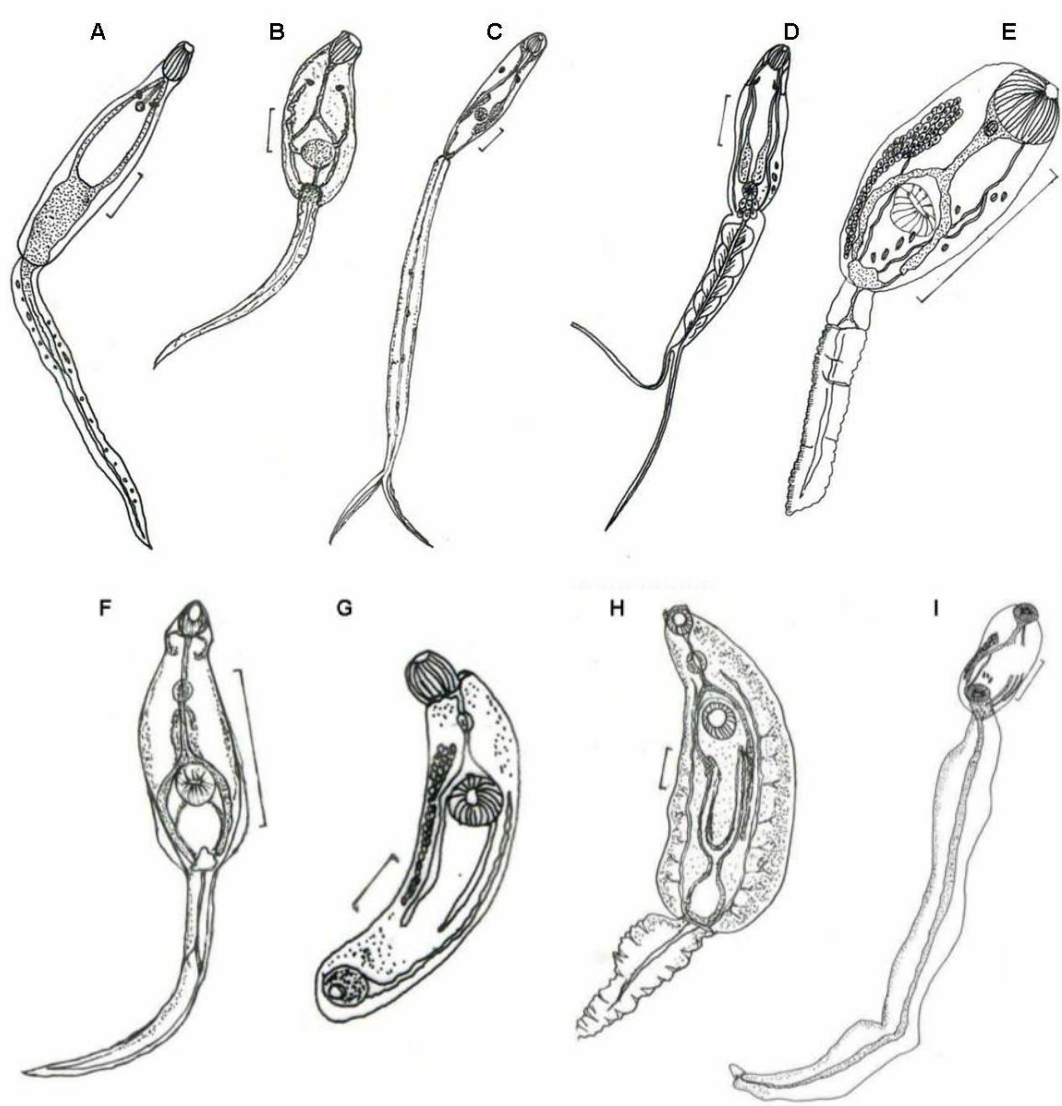

Figure 5. Morphology of the cercariae; (A) Oculopleurolophocercous (Heterophyidae), (B) Distome - unidentified sp., (C) Furcocercous- I -Pseudobilharziella sp., (D) Furcocercous -II - Gigantobilharzia sp., (E)gymnocephalous - (Psilostomidae), (F) Echinostome, (G) Gymnophallus - (Lissorchiidae), (H) Xiphidiocercous- (Astiotrema sp.), (I) Macrocercous cercariae. $($ Scale bar $=\mathbf{5 0} \mu \mathrm{m})$ 


\section{Prevalence of cercariae}

The most prevalent morphotype was oculopleurolophocercous and distome (Family Heterophyidae and an unidentified family, respectively) which were reported from all three zones (Table 4). Diversity of cercariae types differed among the three zones and the highest was reported in the wet zone (Shannon Diversity Index $\mathrm{H}=-1.423$ ) followed by intermediate zone $(\mathrm{H}=-1.306)$. Cercariae diversity was very low in the dry zone $(\mathrm{H}=-0.192)$ where only two types of cercariae (oculopleurolophocercous and distome cercariae) were reported, compared to wet and intermediate zones where six morphotypes were present (Table 4 and Fig. 6). Wet zone and intermediate zone shared the morphotypes; oculopleurolophocercous (Stictodora sp., Family Heterophyidae), furcocercous-II (Gigantobilharzia sp.), gymnocephalous and gymnophallus while macrocercous type was recorded only from the wet zone and xiphidiocercous was found only in the intermediate zone. A mixed infection of oculopleurolophocercous with furcocercous-II was found in a $T$. scabra specimen collected from Mirisgoni Ela.

Prevalence of different cercariae types varied among collection sites (Table 4) with the highest reported from the wet zone being gymnocephalous type (33\%) released by $T$. tuberculata from Mahaweli River. The highest prevalence in the intermediate zone $(27 \%)$ was of oculopleurolophocercous cercariae (Family Heterophyidae ) released by $T$. tuberculata while $100 \%$ prevalence in oculopleurolophocercous cercariae released by the same snail species was reported in the dry zone at Hakwetuna Oya site. Significantly higher number of snails in the dry zone was infected with oculopleurolophocercous than those in the intermediate and wet zone (Chi square test, $\mathrm{p}<0.001$ ).

Highest occurrence of cercarie was in the wet zone infected with gymnocephalous type cercariae (Fig. 6). In the intermediate zone, oculopleurolophocercous type (Family Heterophyidae) and gymnocephalous cercariae were equally abundant. In the dry zone infections consisted only of oculopleurolophocercous and distome type. The highest overall abundant type was oculopleurolophocercous (Heterophyidae; $39.08 \%)$, followed by gymnocephalous $(30.98 \%$; Fig. 6).

Although, the diversity and abundance of snails collected in the dry zone was low, prevalence and intensity of the cercarial infections was very high compared to the wet zone.

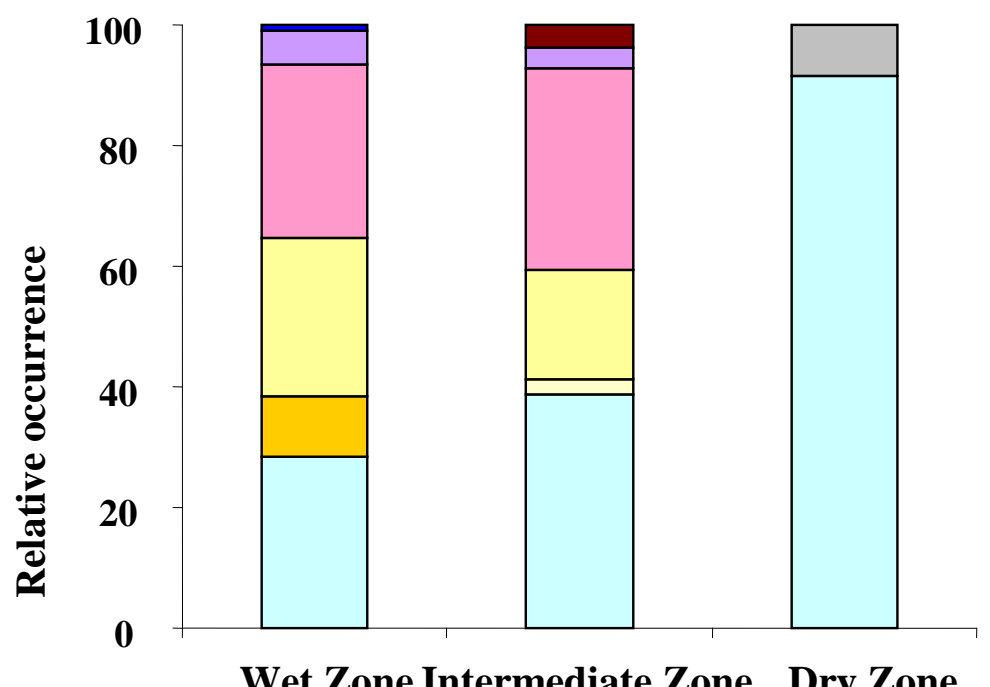

Wet Zone Intermediate Zone Dry Zone

$\begin{array}{lclll}\square \text { O } & \square \text { D } & \square \text { FC } & \square \text { FC } & \square \text { GC } \\ \square \text { EC (F) } \square \text { GP } & \square \text { XI } & \square \text { M } & \end{array}$

Figure 6. Relative occurrence of different types of cercairae in the three climatic zones. OP $=$ Oculopleurolophocercous, $\mathbf{F C}=$ Furcocercous, $\mathbf{G C}=$ Gymnocephalous, $\mathbf{E C}=$ Echinostomous, GP = Gymnophallus, $\mathbf{X I}=$ Xiphidiocercous and MC $=$ Macrocercous . 
Table 4. Prevalence of cercariae morphotypes in different snail species.

\begin{tabular}{|c|c|c|c|c|c|c|c|c|c|c|c|}
\hline \multirow[t]{2}{*}{ Zones/sites } & \multirow[t]{2}{*}{ Snail species } & \multicolumn{10}{|c|}{ \% Prevalence* of Cercariae } \\
\hline & & Overall & OC & DT & FC-1 & FC-2 & GC & EC & GP & $\mathbf{X I}$ & MC \\
\hline \multicolumn{12}{|l|}{ Wet Zone } \\
\hline \multirow[t]{2}{*}{ Mahaweli river } & T. tuberculata & $85.71(42 / 49)$ & 22.45 & - & - & 26.53 & 32.65 & - & 4.08 & - & - \\
\hline & T. scabra & $80(8 / 10)$ & 20 & - & - & 30 & 30 & - & 20 & - & - \\
\hline \multirow[t]{4}{*}{ Sarasavi Oya } & T. tuberculata & $31.25(5 / 16)$ & 31.25 & - & - & - & - & - & - & - & - \\
\hline & T. scabra & $6.14(11 / 179)$ & - & - & - & 6.14 & - & - & - & - & - \\
\hline & P. sphearica & $5.67(53 / 934)$ & - & 0.15 & - & - & 3.74 & - & 0.75 & - & 0.15 \\
\hline & G. saigonensis & $00(0 / 11)$ & - & - & - & - & - & - & - & - & - \\
\hline \multirow[t]{2}{*}{ Maha Oya } & T. tuberculata & $12.39(15 / 121)$ & 4.13 & - & - & 4.13 & 4.13 & - & - & - & - \\
\hline & P. sphearica & $09(1 / 11)$ & 09 & - & - & - & - & - & - & - & - \\
\hline Overall & & $10.14(135 / 1331)$ & 1.83 & 0.70 & - & 2.34 & 4.32 & - & 0.80 & - & 0.07 \\
\hline \multicolumn{12}{|c|}{ Intermediate Zone } \\
\hline \multirow[t]{2}{*}{ Mirisgoni Ela } & T. tuberculata & $48.64(36 / 74)$ & 27.02 & - & 2.70 & 17.56 & - & - & - & 1.35 & - \\
\hline & T. scabra & $28.57(8 / 28)$ & 17.85 & - & - & 3.57 & 10.71 & - & - & - & - \\
\hline \multirow[t]{2}{*}{ Mirisgoni Oya } & T. tuberculata & $40(8 / 20)$ & 15 & - & - & - & 25 & - & - & - & - \\
\hline & T. scabra & $23.81(20 / 84)$ & 9.52 & - & - & 4.76 & 7.14 & - & 1.19 & 1.19 & - \\
\hline \multirow[t]{2}{*}{ Meda Ela } & T. scabra & $38.37(33 / 86)$ & 12.79 & - & - & 6.97 & 15.11 & - & 1.16 & 2.32 & - \\
\hline & P. sphearica & $00(0 / 18)$ & - & - & - & - & - & - & - & - & - \\
\hline Overall & & $33.87(105 / 310)$ & 15.16 & - & - & 7.74 & 8.71 & - & 0.06 & 1.29 & - \\
\hline \multicolumn{12}{|l|}{ Dry Zone- } \\
\hline Мa Oуa & T. scabra & $42.10(8 / 19)$ & 36.84 & - & - & - & - & 5.26 & - & - & - \\
\hline Hakwetuna Oya & T. tuberculata & $100(13 / 13)$ & 100 & - & - & - & - & - & - & - & - \\
\hline Ibi Ela & T. scabra & $95.23(20 / 21)$ & 90.47 & - & - & - & - & 4.76 & - & - & - \\
\hline Overall & & $77.35(41 / 53)$ & 73.58 & - & - & - & & 3.77 & - & & - \\
\hline
\end{tabular}

* Prevalence of a morphotype $=$ No. of snails infected with the morphotype /total number of snails collected. OC=oculopleurolophocercous, DT= distome, $\mathrm{FC}=$ furcocercous, $\mathrm{GC}=$ gymnocephalous, $\mathrm{EC}=$ echinostomous, $\mathrm{GP}=$ gymnophallus, $\mathrm{XI}=$ xiphidiocercous and $\mathrm{MC}=$ macrocercous. 


\section{DISCUSSION}

The present study reports cercariae of nine species of digenetic trematodes belonging to eight morphotypes in freshwater snails collected from three different climatic zones of Sri Lanka. Of the 1694 snails collected, 16\% (284) were found infected with cercariae. A high infectivity was observed in the dry zone where $77.4 \%$ of the snails were infected followed by the $33.9 \%$ in the intermediate zone. Cercariae infection was very low in the snails collected from the wet zone $(10.1 \%)$. High prevalence of infection in the dry zone could be due to slow flowing, low levels of water in the streams and high contamination by the faecal matter of livestock, birds and wild animals. On the other hand, fastflowing high water levels in wet zone streams flushes off of the faecal matter reducing the chances of snails getting the infection. It is also likely that since snail abundance is low in the dry zone, miracidia enter all the snails available in the habitat. Skirnisson et al. (2004) analyzed the influence of several abiotic and biotic variables on the distribution of digenetic trematode infections in mudsnail, Hydrobia ventrosa, populations inhabiting 12 ponds on the Melabakkar salt marsh in Iceland and found that factors which determine the attractiveness of the ponds to the final hosts and their habitat use and defaecating habits are the main determinants of the trematode distribution in the area. For trematode infected snails, spatial variation in infection can easily arise as a consequence of the distribution of second intermediate and final hosts and/or habitat characteristics which affect the risk of infection (Curtis and Hurd, 1983; Fernandez and Esch, 1991; Sousa, 1994).

Diversity of digenean fauna is dependent on conditions that are conducive for transmission such as the presence of final and intermediate host (Gardner and Campbell, 1992). Even though, prevalence of infection was high in the dry zone, the diversity of infection was low compared to the intermediate and wet zones. This might be due to the absence of adult parasites due to the absence of the definitive host in the dry zone. However, it is unlikely that low diversity in the snail fauna in the dry zone contributes to low cercariae diversity as the same snail species (Thiara spp.) harboured seven different types of cercariae in the intermediate and wet zones. Studies have showed a consistent relationship between the density and heterogeneity of the snail populations with the trematode density and heterogeneity (Hechinger and Lafferty, 2005). The results of the present study are consistent with the heterogeneity of trematodes but not with the density of trematodes. Higher number of snail species did not support a higher density of trematodes.

However, as a consequence of the direct interference of trematodes on snail egg production and their mortality rates, trematode prevalence is not directly related to the snail population density (Lafferty, 1993). Considering trematode induced castration in snails, trematodes might have strong influence on the snail populations. Granovitch et al. (2000) reported Microphallus piriformes infection causing more than half of the periwinkle population, devoid of reproduction. Similarly, snail populations in the dry zone might have a castration effect of the existing trematode infections in the area resulting very low population density.

Of the five snail species, Thiara spp were by far the most heavily infected snail host. It also showed a high diversity, supporting cercariae of Gigantobilharzia sp., Pseudobilharziella sp., gymnocephalous, echinostomous, gymnophallus, xiphidiocercous and macrocercous cercariae. Thiara spp. were the only snail species found in the dry zone and were widely distributed where as in the wet zone, Paludomus sphearica had a wide distribution $(71.0 \%)$ which was infected with four types of cercariae. Of the two Thiara spp., T. scabra was more common in both intermediate $(63.9 \%)$ and dry $(75.4 \%)$ zones. Thiara tuberculata and T. scabra collected in the intermediate zone each harboured five types of cercariae while the two species collected from wet zone, each harboured four types of cercariae. The two snail species collected from the dry zone were infected only with two types of cercariae. This shows that the distribution of cercariae types depends on the presence of the definitive host and therefore the adult parasites but not on the presence of snail intermediate host.

Faizal (2000) has reported nine types of cercariae collected from a site in Kalametiya Oya, in Matale district. However, during this study we were unable to sample snails from Kalametiya Oya due to heavy sedimentation in the stream as a result of ongoing construction activities around the area. Sedimentation can interfere the trematode life cycle by preventing miracidia from finding the host, reducing egg supply and the survival of host snail (Faloon et al., 1996). Environmental changes following 
irrigation development are likely to modify the pattern of distribution of snails and trematodes. Consequently, the cercariae shed by snails can be used to assess the environment impact (Lafferty, 1997) as well.

The development of all the true monostomes is not completed in the redia stage but, in the tissues of the snail host, out of which they penetrate under suitable temperature and pressure (Wesenburg-Lund, 1931). Hence, they are highly specific in search of their snail host. Furthermore, providing enough sunlight to induce cercarial shedding is an important step to stress the snail. oculopleurolophocercous (Order- Opisthorchiiformes, familyHeterophyidae) are parasites in the intestines of fish and reptiles (Brooks et al., 1985). Gigantobilharzia and Pseudobilharziella spp. (Order-Strigeiformes, super familySchistosomatoidea, family- Schistosomatidae) are blood parasites of birds and mammals. Gymnophallus cercariae (Order-Strigeiformes, super family- Gymnophalloidea, familyGymnophallidae) are small species of trematodes found in the gall bladder, intestine and bursa fabricii of birds (Wesenburg-Lund, 1931). Digenetic trematodes belonging to family Psilostomidae (Order- Echinostomatiformes, super family- Psilostomoidea) infect kidneys, and intestines of mammals, birds and snakes (Brooks et al., 1985).

Iwagami et al. (2009) reported that Paragonimus westermani utilizes Paludomus sp. as the molluscan intermediate host in the wet zone of Sri Lanka. Gymnophallus reported in this study closely resembled the cercariae of Paragonimus even though it is larger $(338 \mu \mathrm{m})$ than the cercariae of Paragonimus $(174.5 \mu \mathrm{m})$. Xiphidiocercariae reported in this study closely resembled the Cercariae vesiculosa, described by Wesenburg-Lund (1931). However, the xiphidiocercariae found in the present study can be placed in the Family Lecithodendriidae (Order Plagiorchiiformes, Suborder Plagiorchiata, Superfamily Lecithodendroidea) which are parasites of insects, amphibians, lizards, snakes, birds and mammals (Brooks et al., 1985). However, confirmation to the species level requires DNA studies.

This study provides preliminary information about the distribution and prevalence of trematode species based on identification of larva. Although identification of cercariae to species level using fine characteristics like, nervous system elements, sensory apparatus, body papillae such cheatotaxy is possible (Husanov and Yadev, 2005) it is very laborious and subjective. Therefore DNA analysis is a better reliable method.

\section{ACKNOWLEDGEMENTS}

Authors thank Pradeep Samarawickrama, Varuni Imbuldeniya, Samartha Harischandra, Wasana Hemachandra and Nayana Wijetilake for technical assistance. Financial assistance by the National Science Foundation, Sri Lanka (Grant No. RG/2005/EB/02) is acknowledged.

\section{REFERENCES}

Anderson, R.M. and May, R.M. (1991). Infectious Diseases of Humans: Dynamics and Control (Oxford Univ. Press, Oxford, U.K.).

Brooks, D.R., O'Grady, R.T. and Glen, D.R. (1985). Phylogenetic analysis of the Digenea (Platyhelminthes: Cercomeria) with comments on their adaptive radiation. Canadian Journal of Zoology 63: 411- 43.

Cheng, T.C. (1986). The Biology of Animal Parasites, W.B. Saunders Company, Philadelphia and London. 243-48 pp.

Combes, C., Fournier A., Mone, H., and Theron M. (1994). Behaviours in trematode cercariae that enhance parasite transmission: Patterns and processes. Parasitology. 109: S3-S13.

Cutis, L.A. and Hurd, L.E. (1983). Age, sex, and parasites: spatial heterogeneity in a sandflat population of Hyanasaa obsolete. Ecology 64: 819-829

Faizal, M. (2000). A preliminary study of the cercariae of digenetic trematodes in Kalametiya Oya (Intermediate zone) of Sri Lanka. M. Sc. Thesis, Postgraduate Institute of Science, University of Peradeniya.

Faloon, K.E. and Michel, E. (1996). Trematode parasite prevalence in Lavigeria: The effect of sedimentation, depth, size and species. The Nyanza Project 2002 Report.

Falty'nkova' A., Našincova' V., and Kabla'skova L. (2008) Larval trematodes (Digenea) of planorbid snails (Gastropoda: Pulmonata) in Central Europe: a survey of 
species and key to their identification Systematic Parasitology 69: 155-178.

Fernandez, J. and Esch G.W. (1991). Guild structure of the larval trematodes in the snail Helisoma anceps: patterns and processes at the individual host level. Journal of Parasitology 77: 528-539.

Gardner, M. and Campbell, L.C. (1992). Parasites as probes for biodiversity. Journal of Parasitology. 78. 596-600.

Granovitch, A.I., Sergievsky, S.O. and Sokolova, I.M. (2000). Spatial and temporal variation of trematode infection in coexisting populations of intertidal gastropods Littorina saxatilis and L. obtusata in the whilte sea. Diseases of Aquatic Organisms. 41: 53-64.

Hechinger, R.F. and Lafferty, K.D. (2005). Trematodes in snail intermediate hosts. Host diversity begets parasite diversity: bird final hosts and trematodes in snail intermediate hosts. Proceedings of the Royal Society. 272: 10591066.

Hrusanov, D. and Radev, V. (2005). Cheatotaxy of cercariae obtained from Lymnaeid freshwater snails. Experimental Pathology and Parasitology 8: $99-104$.

Iwagamia, M., Rajapakse R.P.V.J., Yatawara L., Kano S and Agatsuma, T. (2009) The first intermediate host of Paragonimus westermani in Sri Lanka Acta Tropica 109: 27-29.

Lafferty, K.D. (1993). Effects of parasitic castration on growth, reproduction and population dynamics of the marine snail Ceritedia californica. Marine Ecology Preogress Series 96: 229-237.

Lafferty, K.D. (1997).Environmental parasitology: What can parasites tell us about human impact on the environment? Parasitology Today 13: 251-255.

Margolis, L., Esch, G.W., Holmes, J.C., Kuris, A.M. and Schad, G.M. (1982). The use of ecological terms in parasitology (report of an adhoc committee of the American Society of Parasitologists). Journal of Parasitology 68:131-133.
Mendis, A.S. and Fernando, C.H. (2002) A guide to the freshwater fauna of Ceylon. In (Eds: Fernando C.H. and Weerewardhena SR) Sri Lanka Freshwater fauna and fisheries. Pp. 51-59.

Naggs, F., and Raheem, D. (2000). A Coloured guide to the Land and Fresh water Mollusks of Sri Lanka. The Natural History Museum. The Darwin Initiative Programme. London.

Poulin,R. (2005). Global warming and temperature mediated increases in cercarial emergence in trematode parasites. Parasitology 132: $143-151$

Shostak, A.W. and Esch G.W. (1990). Photocycle-dependent emergence by cercariae of Halipegus occidualis from Helisoma anceps, with special reference to cercarial emergence patterns as adaptations for transmission. Journal of Parasitology 76: 790-795.

Skirnisson, K. Glaktionov, K and Kozminsky, E. (2004). Factors influencing the distribution of digenetic trematode infections in a mudsnail (Hydrobia ventrosa) population inhabiting salt marsh ponds in Iceland. Journal of Parasitology 90: $50-59$.

Smyth, J.D. (1962). Introduction to Animal Parasitology, Cambridge University Press. Pp 196-198.

Sousa, W.P. (1994). Pattern and processes in communities of helminth parasites. Trends in Ecology and Evolution 9: 4-57.

Wesenberg-Lund, C. (1931). Contributions to the development of the Trematoda Digenea. Part II. The biology of the freshwater cercariae in Danish freshwaters. Mémoires de l. Academie Royale des Sciences et des Lettres de Danemark, Copenhague, Section des Sciences 9: 1-.223.

Yamaguti, S. (1975). A synoptical review of life histories of digenetic trematodes of vertebrates. Keiguku Publication Co. Tokyo, Japan. Pp. 590. 